\title{
Frost damage on the terminal shoot as a risk factor of fork incidence on common beech (Fagus sylvatica $\mathbf{L}$.)
}

\author{
François NINGRE*, Francis COLIN
}

INRA, Unité Mixte de Recherches INRA-ENGREF, Laboratoire d'études des ressources Forêt-Bois, Équipe Croissance et Production, Nancy, France

(Received 27 September 2005; accepted 16 March 2006)

\begin{abstract}
Forking is a frequent flaw in beech which can adversely affect the formation of high quality logs. Even though the hypothesis that late frosts increase forking is widely accepted by forest managers, it remains to be proved and quantified experimentally. Damage caused by a late frost on 15 May 1995 to young beech trees in an experimental site at Lyons-La-Forêt (France) and the consequences on the development of forking were analysed. The beech trees were 17 years old with heights between 1.5 and $9 \mathrm{~m}$. Of all the plantation densities tested only the lowest density (625/ha) showed various and severe frost damage. Three levels of immediate damage to the growing terminal shoot were observed, with increasing intensity from: (1) no trace of frost damage, (2) reddened leaves and (3) frost-nipped shoots. The intensity of visible damage to the terminal shoot appeared to be very dependent on the height of the plant which justified our original experimental approach, based on an evaluation of the damage for each individual. Almost all of the beech trees less than $4 \mathrm{~m}$ high suffered frost damage and all those taller than $7 \mathrm{~m}$ were unaffected. Three-year-old forks due to frost which occured in May 1995 were recorded at the end of 1997 using an objective definition based on dendrometric and age criteria. The worst frost damage resulted in a significant increase in the risk of fork emergence ( $71.7 \%$ of the plants were forked). With a risk related to forking in the presence of frost-nipped shoots equal to 2.15 and a fraction of the attributed risk of 0.36 it was concluded that the late frost observed played a significant role in the degradation of the shape of the beech affected by frost and the overall quality of the stand.
\end{abstract}

forks / Fagus silvatica / frost damage / relative risk / attributive fraction of risk / plantation

\begin{abstract}
Résumé - Les dégâts de gel tardif sur la pousse terminale : un facteur de risque d'apparition de fourches chez le hêtre (Fagus sylvatica L.). La fourchaison est un défaut fréquent du hêtre qui peut nuire à la formation d'une grume de qualité. L'hypothèse d'un effet des gelées tardives contribuant à aggraver la fourchaison, bien que largement admise par les gestionnaires forestiers, restait pourtant à démontrer et à quantifier dans un cadre expérimental. Les dégâts occasionnés par la gelée tardive du 15 mai 1995 sur de jeunes plants de hêtre du dispositif expérimental de Lyons-La-Forêt (France) et leurs conséquences sur la mise en place de fourches ont été analysés. Les hêtres étaient alors âgés de 17 ans et de hauteur comprise entre 1,5 et $9 \mathrm{~m}$. Parmi toutes les densités de plantation testées seule la plus faible (625/ha) présentait un impact fort et diversifié du gel. Trois niveaux d'intensité croissante de dégâts immédiats sur la pousse terminale en élongation ont pu être distingués : (1) aucune trace de gel, (2) feuilles roussies (3) pousse gelée. L'intensité des dégâts visibles sur la pousse terminale est apparue très dépendante de la hauteur du plant justifiant notre approche expérimentale originale centrée sur l'évaluation individuelle des dégâts. La quasi totalité des hêtres de hauteur inférieure à $4 \mathrm{~m}$ avaient gelé et tous ceux de hauteur supérieure à $7 \mathrm{~m}$ étaient indemnes. Les fourches imputables au gel ont été inventoriées fin 1997 selon une définition objective basée sur des critères dendrométriques et sur un critère d'âge. Le dégât de gel le plus intense a eu pour conséquence une augmentation significative du risque de fourchaison ( $71,7 \%$ de plants fourchus). Avec un risque relatif de fourchaison en présence de pousse gelée égale à 2,15 et une fraction du risque attribuable de 0,36 on peut conclure que le gel tardif observé contribue notablement à la dégradation de la forme du hêtre touché par le gel et à la qualité globale du peuplement.
\end{abstract}

fourches / Fagus silvatica / dégât de gel / risque relatif / fraction du risque attribuable / plantation

\section{INTRODUCTION}

At the beginning of its growth, at least in open ground, a young beech is often exposed to late spring frosts. Damage is observed on all or part of the tree: reddened leaves, or frostnipped shoots, sometimes in a spectacular way $[16,23]$. Severe changes in the leaf structure result in a loss of height growth or diameter which can have repercussions for several years $[16,20,29]$, penalising young plantations in particular. In some extreme cases, frost can even kill young plants.

This high risk for beech, has led plant breeders to select provenances for planting or replanting with late bud burst,

\footnotetext{
*Corresponding author: ningre@ nancy.inra.fr
}

which is known to be under strong genetic control and stable over time [30]. This selection should reduce the risk of frost damage but cannot eliminate it entirely. Peik [28] did not observe any provenance with bud burst which was late enough to be unaffected by frost. Conversely, Galoux [15] remarked that in the case of exceptionally late frosts in June, beech trees which had outburst early, thus having tissue which was resistant already, were unaffected as opposed to those with late bud burst.

Even greater than the real risk to vigour loss, are the consequences of late frosts on the shape of the beech which are a cause for worry. In fact, frosts are generally associated with forking. Risk of frost damage is renowned for being the 
greatest in the first $2 \mathrm{~m}$ above ground level [12,31], and the emergence and persistence of a fork at this level would inevitably result in a reduction in the length of the butt $\log$ and in the market value of the tree.

Even if this is commonly known, the hypothesis of a close relationship between frost and forking is based essentially on unquantified field observations or an a priori evident belief. The destruction of the terminal bud by frost is assumed to be the factor which increases the risk of fork emergence in beech [22], as demonstrated for ash [26]. This assumption for beech seems to be based at first on a study by Kurth [21] who in describing and following the development of a few young beech trees which had suffered frost damage, observed the presence of forks on some of them, thus reducing their value. This assumption seems also based on a study by Galoux [15] who carried out a survey of the best shape of stems (using an overall impression of straightness) on young material genetically selected for late bud burst and so theoretically less exposed to frost. Finally, in a Bulgarian experiment, Botev [9] observed at 4, 5, 10 and 18 years after plantation that the proportion of trees with "bifurcated shoots" was the highest the year when frost damage occurred.

These studies, as well as a multitude of observations reported by other authors $[13,17,23,31]$ are not very convincing: the visible effects of frost were not quantified, the forks were rarely well defined and finally the experimental designs did not allow for comparison with beech trees which were not frost damaged. Finally, although the hypothesis that late frosts have an effect on forking is widely accepted, the cause-andeffect relationship between frost damage and the emergence of forks has not been proved formally.

For this reason the aim of our research was to demonstrate this cause-and-effect relationship and to quantify the effect of damage on forking. We took advantage of a young open experimental beech plantation whose genetic origin, site conditions and environment in the vicinity of the trees were known factors, and the trees were at a stage of development when the future butt $\log$ is defined.

It is important to stress here that we "took advantage" of the exceptional frost in May 1995 to set up this study on an experimental site which had been installed since 1981 . We were not able to measure the characteristics of the late frost in the plot, or in the experimental site, or even at the individual tree scale. On the other hand, we were able to describe accurately the damage caused by this frost. Our aim was thus not to prove a relationship between the abiotic factor "late frost" and immediate forking, but between the damage to the plant observed just after the frost and the forking produced 3 years later. So our study remains entirely within the field of morphogenesis.

\section{MATERIALS AND METHODS}

\subsection{Experimental site}

This study was carried out in an experimental beech plantation installed in the spring of 1981, in the state forest of Lyons-laForêt (Seine Maritime: Latitude $49^{\circ} 28^{\prime}$, Longitude $1^{\circ} 34^{\prime}$ ) in a site favourable for beech culture. It was situated in a flat forest plot at an altitude of $190 \mathrm{~m}$, with a homogeneous 45 to $65 \mathrm{~cm}$ deep leached brown soil. The climate was oceanic with slightly continental tendencies with average annual temperature of $10.5^{\circ} \mathrm{C}$ and average annual precipitation of $883 \mathrm{~mm}$ (period between 1992 and 2000, Boos station near Rouen). From 1958 to 1988, the percentage of years with temperatures at or below $0{ }^{\circ} \mathrm{C}$ after 20 April was $57 \%$, and $27 \%$ after 1 May.

The experimental site, set up in an open environment without any vertical or lateral cover, consisted of six treatments corresponding to the following six initial planting densities: 625, 2500, 4444, 5000 , 10000 and 40000 plants per ha. The site was set up in blocks with a total area of 3 ha. Successive interventions have eliminated the other vegetation so that aerial and root competition only occurred between the planted beech trees. The 3-year-old $(1+2)$, bare-rooted plants with a mean height of $50 \mathrm{~cm}$ were all of the same local origin (Arques state forest in Normandy).

During the night of 14/15 May 1995, a frost affecting the whole of France [23] was particularly severe in the experimental site. The beech trees were 17 years old at that time and were between 1.5 and $9 \mathrm{~m}$ high. The minimum temperature, recorded at a height of $1.5 \mathrm{~m}$ by a maximum-minimum thermometer at a forest house situated nearby in the state forest of Lyons-La-Forêt, reached $-7^{\circ} \mathrm{C}$. Preliminary observations over the whole of the site showed that (i) the highest frequency of trees with severe damage and (ii) the most diverse damage, to young shoots and leaves at the beginning of their spring growth, were confined to two plots, P1 and P2, where tree density was the lowest, initially $625 / \mathrm{ha}$.

The severity of certain damage observed, specifically in this density $625 / \mathrm{ha}$, might be explained by high initial spacing leading to numerous gaps, where cold and thus dense air can accumulate. In the denser plots in addition, dominant trees create a more or less continuous cover that protect smaller trees [3].

Finally concentrating our observations in a unique density allowed us not having to test interacting density effects. So our study was carried out on the 209 beech trees in these 2 plots, P1 and P2, which were about $200 \mathrm{~m}$ apart, with densities in 1995 which were slightly lower than the initial density (450/ha and 550/ha respectively).

\subsection{Methods}

\subsubsection{Survey of frost damage}

An accurate survey of frost damage was made 3 weeks after the frost on 15 May 1995. Damage was exclusively recorded on the terminal spring shoot of the main axis. This local observation is more accurate than the overall impression of the tree used by Galoux [15] from which it was derived.

Thus it was possible to distinguish 3 levels of damage: (1) plants whose shoots were undamaged ("undamaged" level), (2) plants where only the leaves were damaged and showed red marks on the lamina ("red spots" level), and (3) others whose shoots were totally destroyed and dried-up ("frost-nipped shoot" level). These 3 levels, of increasing visible frost damage intensity, were observed from the base of the tree, using binoculars (Perl $8 \times 56)$ if necessary. 


\subsubsection{Fork survey in 1997}

A fork is a morphology consisting of a portion of the stem axis surmounted by two axes (or two arms of the fork) originating from the same point.

The forks observed in this study were those which emerged on the annual shoot of the principal axis of each plant in 1994. According to the definition proposed in [25], these forks were only recorded 3 years after the frost, i.e. at the end of 1997. The presence of these forks, however many per shoot, determined whether the plant was forked or not. We did not record forks emerging after the spring of 1995 on annual shoots developed before 1994. It was impossible to exclude the fact that such forks might have appeared but we supposed that they would have been limited in number.

\subsubsection{Growth survey}

Total height and girth at $0.2 \mathrm{~m}$ were measured regularly every year from the winter 1994/1995 to the end of 1997.

\subsection{Statistical analysis}

All the statistical analyses were carried out using the SAS version 8.2 software using procedures PROC FREQ, PROC LOGISTIC and PROC GLM

The effect of frost damage intensity on the proportion of forked beech trees was tested using a Chi squared test on a $3 \times 2$ contingency table ( 3 damage levels $\times$ presence or absence of a fork). A risk of fork emergence was calculated for each of the damage levels. The relative risk of fork emergence, with its confidence limit (at $5 \%$ of risk level), was calculated for each of the damage levels, "red spots" and "frostnipped shoot" relative to the "undamaged" level [10].

The relationship between the presence of forks per plant (classified in a binary form: no forks, at least one fork) and the variables: plant height after vegetation period 1994, level of damage, plot and the different first order interactions, were analysed by adjusting a logistic model. The selected model was specified in terms of P-value from Chi-2 test and the part of variability it explains was quantified by the two forms of generalised coefficients of determination Rsquare and Max-rescaled Rsquare (proposed by Cox and Snell, and Nagelkerke respectively, see [8]). The comparison of the different levels of damage was carried out using the method of contrasts, allowing pairwise comparisons of treatments based on P-values of Chi-2 test.

In addition to the quite "classic" determination of risk, relative risk and its confidence interval, we applied the concept of attributive fraction of risk (AFR). Whereas the relative risk value is a precious indicator at the scale of an individual, this second concept takes the importance of the risk factor at the plant population level into account, i.e. the proportion of the different types of damage. This attributive fraction of risk (AFR) was calculated as follows [10]:

$$
\mathrm{AFR}=\left[\sum_{i=0}^{\mathrm{n}} \mathrm{P}_{i} \cdot \mathrm{RR}_{i}-1\right] /\left[\sum_{i=0}^{\mathrm{n}} \mathrm{P}_{i} \cdot \mathrm{RR}_{i}\right]
$$

where $\mathrm{RR}_{i}$ was the relative forking risk for the damage level, $i$, relative to the "undamaged" level ( $i$ varies from 0 to 2, conventionally $i=0$ and $\mathrm{RR} 0=1$ for the reference level, in our case the "undamaged" level), and $\mathrm{P}_{i}$ was the proportion of plants exposed to level $i$ damage.

Finally, for each of the 3 years following the frost, a one way analysis of variance was used to compare annual growth depending on the level of damage.

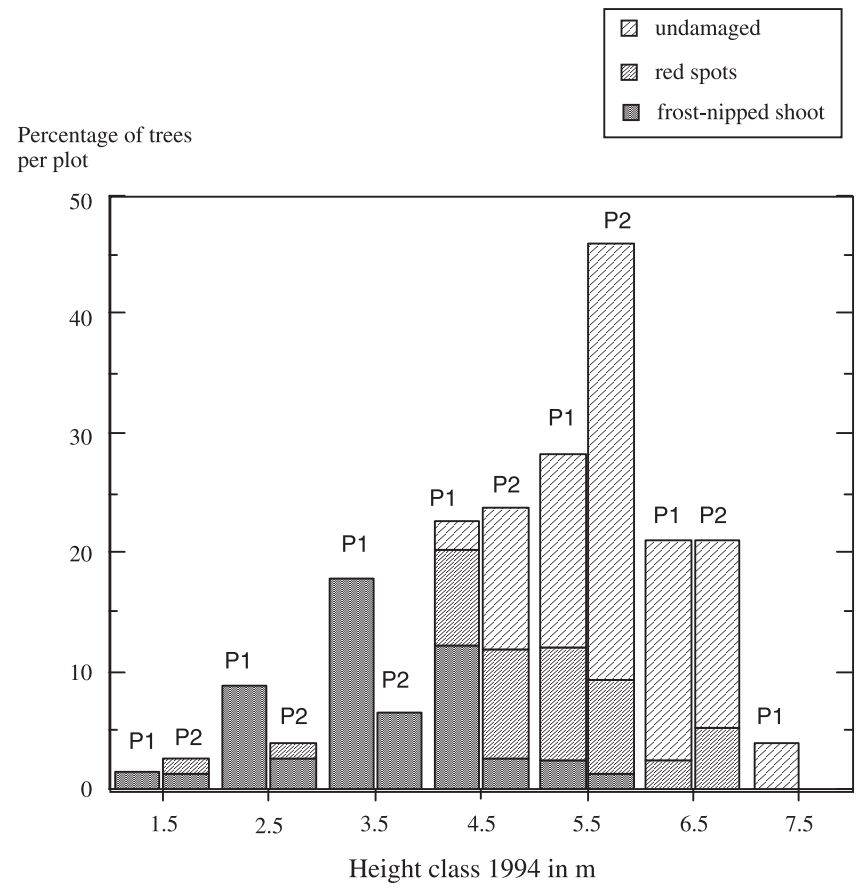

Figure 1. Distribution of damage on the terminal shoot of the principal axis by height class in 1994, for each of the 2 plots (P1 and P2)

\section{RESULTS}

\subsection{Intensity of frost damage depending on tree height in 1994}

It was the smallest trees, which were well represented in plot P1, that were the most affected by this frost (Fig. 1). The terminal shoots of almost all trees smaller than $4 \mathrm{~m}$ (45 in total), except for 2 trees in plot P2, were destroyed. However, above $4 \mathrm{~m}$, the proportion of plants with damaged terminal shoots, which was the lowest in plot $\mathrm{P} 2$, decreased rapidly to none above $5.5 \mathrm{~m}$. Similarly it was on trees between 4 and $7 \mathrm{~m}$ that leaves with red spots were mainly observed. The fact that the damage occurred below $7 \mathrm{~m}$ and intensively in the first $4 \mathrm{~m}$ confirmed the extreme severity of the late frost studied.

Figure 1 shows also for height classes 4.5 and $5.5 \mathrm{~m}$ the lower proportion of "frost-nipped" trees from plot P2 than from plot P1. In addition to the differences of height already reported between both plots, this additional observation suggested that the frost had different characteristics in the 2 plots.

\subsection{Forking frequency}

Table Ia demonstrates that the frequency of forked plants was significantly dependent on the level of damage observed (the Chi-2 test was highly significant, $P=0.0004$ ). The relative risk of fork emergence in the presence of a frost-nipped shoot, was equal to 2.15 (the confidence limits are between 1.4 and 3.28). This demonstrated a large and significant increase 
in forking at this damage level. The intermediate "red spots" damage level, showed a forking risk with values intermediate between those of the "undamaged" and "frost-nipped shoot" levels. The calculated relative risk, although above 1, was not significantly different from 1 (the confidence limits were between 0.85 and 2.53, and thus included the value of 1 ); this meant that in the presence of damage "red spots", the risk of fork emergence was not significantly increased relative to undamaged plants.

A so detailed analysis was not possible for plot $\mathrm{P} 2$ since the too few individuals (only 3) unforked in 1997 and with frostnipped shoots in 1995 did not permit to use the Chi-2 test. However we present the proportions in Table Ib and the risk values, which follow the same trends as for plot P1.

The contingency table for plots 1 and 2 together is provided in Table Ic. We obtain a relative risk of fork emergence of 1.9 (significantly different of 1 ) for frost-nipped shoots and a relative risk of fork emergence of 1.31 (non-significantly different of 1) for "red spots" trees.

It should be noted that the plants for which two forks were recorded (two forks being the maximum observed) were infrequent whatever the plot or the damage level. There was a total of 15 (data not shown) amongst the 107 forked plants (Tab. Ic).

The logistic model applied to the probability of the presence of forks in plots P1 and P2 together, made it possible to test simultaneously the effect of the available variables and factors: damage level, height in 1994, plot, and the interactions of plot $\times$ damage level, and plot $\times$ height in 1994 . Finally, only the damage factor appeared to be significant (Tab. II). The selected model is:

$\log ([$ proba(presence of forks $)] /[1-\operatorname{proba}($ presence of forks $)])$ $=$ intercept $+B_{\text {damage }}$.

The part of the variation explained by this model (maxrescaled $R$ square $=0.12$ ) remains low but this was logical if one takes into account the high proportion of forked plants which were not linked to frost-related accidents (33.3\%). This model was, however, better than the one which only retained the height reached at the end of 1994 (not shown, max-rescaled Rsquare $=0.08$ ), a model tested due to the strong correspondence observed between height and damage level.

The estimates and the $P$-value Chi-2 test of nullity of the parameters intercept, $\mathrm{B}_{\text {frost-nipped }}, \mathrm{B}_{\text {red-spots }}$ and $\mathrm{B}_{\text {undamaged }}$ are provided in Table IIb, in which $\mathrm{B}_{\text {frost-nipped }}$ is arbitrary fixed to 0 .

Only the effect of the "frost-nipped shoot" level was significantly different to the "undamaged" level (Tab. IIc). This was obtained on the one hand from the amalgamated data of plots 1 and 2, with a high total number $(\operatorname{Pr}>$ Chisq $=0.0008)$ and on the other hand from data of plot P1 $(P r>$ Chisq $=0.004)$. The logistic model showed that the differences of effect were significant neither between the "red spots" and "undamaged" levels on the one hand $(\operatorname{Pr}>$ Chisq $=0.18)$, nor between the "red spots" and "frost-nipped shoot" levels on the other hand $(\operatorname{Pr}>$ Chisq $=0.50)$.

\subsection{Attributive fraction of risk}

Relating to plot P1, AFR $=0.36$ (Tab. Ia). This meant that at the scale of all the plants in plot $\mathrm{P} 1$, the additional fraction of plants with forks which could be attributed to damage following the late frost of 15 May 1995, represented 36\%. AFR calculated for plots P1 and P2 together (Tab. Ic) is only 0.26 .

\subsection{Damage intensity and subsequent height growth}

We considered height growth between 1995 and 1997. Taking the fact that intermediate damage did not significantly increase fork emergence, the only relevant comparison was that between the beech trees with frost-nipped shoots and the undamaged ones (Fig. 2). In the 3 years following the frost, annual height growth increment of the beeches with frost-nipped shoots remained regularly low, the median values changed from $34.4 \mathrm{~cm}$ (in 1995) to $25.1 \mathrm{~cm}$ (in 1997). Beech trees with annual elongation rate higher than $50 \mathrm{~cm}$ were in the minority $(8,9$ and $17 \%$ of trees with frost-nipped shoots respectively in 1996, 1995 and 1997). Height growth of the undamaged beech trees was significantly higher than those with frost-nipped shoots $(p<0.0001)$, with a maximum in 1995 (the median value was $67.8 \mathrm{~cm}$ ).

\section{DISCUSSION}

This type of experiment is known as a prospective cohort study, according to the terminology used in epidemiology, using a group exposed to a risk factor, this being the damage due to late frost (and not to the frost itself), compared with an unexposed group [10]. The fact that one can only use the information that the frost has given us, as damage distribution, incorporated a certain number of constraints into our experiment. Thus, the number of trees in the different damage levels was not identical. Similarly, the undamaged trees were higher than the damaged trees. Finally, it appears that plot P2 contained a very low percentage of trees with frost-nipped shoots in spite of the general impression of severe damage. Conversely, this experimental method has the advantage of allowing one to bypass the frost itself in a way, as its characteristics are always difficult to define accurately at the tree scale.

This type of experiment also has the advantage that the relative risks can be calculated easily. It should be noted that this concept is little used in forestry, or in morphological studies. However it seems to be essential to obtain an accurate evaluation of the effect of a risk factor. The results presented were obtained using an original, methodological approach centred on the careful description of damage, caused by a late frost for which the exact characteristics were unknown.

Our study was thus fundamentally different from previous studies trying to link late frosts with forking, like that of Kerr and Boswell [19] for example, where neither the frost characteristics nor the immediate damage it caused were known.

To predict this damage retrospectively, supposed that we were capable of taking into account statistically the local intensity of the frost (modified by the environment around the 
Table I. Distribution of forked and unforked trees in plots P1 and P2, individually (Tabs. Ia and Ib respectively) and then together (Tab. Ic), depending on frost damage intensity on the terminal shoot (Contingency table $3 \times 2$ ). Details of calculating risk of fork emergence for the "frost-nipped shoot" damage level, and relative risk of fork emergence for the "frost-nipped shoot" damage level relative to the "undamaged" level are provided in Table Ia.

\begin{tabular}{|c|c|c|c|c|c|c|c|}
\hline \multirow[t]{2}{*}{ Ia (Plot P1) } & & \multicolumn{2}{|c|}{$\begin{array}{c}\text { Observed frequency } \\
\text { of trees }\end{array}$} & \multirow[t]{2}{*}{ Total } & \multirow[t]{2}{*}{$\begin{array}{c}\text { Risk of fork } \\
\text { emergence } \%\end{array}$} & \multirow[t]{2}{*}{$\begin{array}{l}\text { Relative risk of } \\
\text { fork emergence }\end{array}$} & \multirow{2}{*}{$\begin{array}{c}\text { Confidence limit of the } \\
\text { relative risk } \\
\text { of fork emergence }\end{array}$} \\
\hline & & Forked & Unforked & & & & \\
\hline \multirow{4}{*}{$\begin{array}{l}\text { Levels of } \\
\text { damage }\end{array}$} & Frost-nipped shoot & 38 & 15 & 53 & $71.7=100 .(38 /(38+15))$ & $2.15(=71.7 / 33.3)$ & {$[1.40-3.28]$} \\
\hline & Red spots & 12 & 13 & 25 & 48.0 & 1.44 & {$[0.82-2.53]$} \\
\hline & Undamaged & 17 & 34 & 51 & 33.3 & - & - \\
\hline & Total & 67 & 62 & 129 & & & \\
\hline
\end{tabular}

Calculated statistics of Chi-square $=15.5$; degree of freedom $=2 ; p$-value $=0.0004$

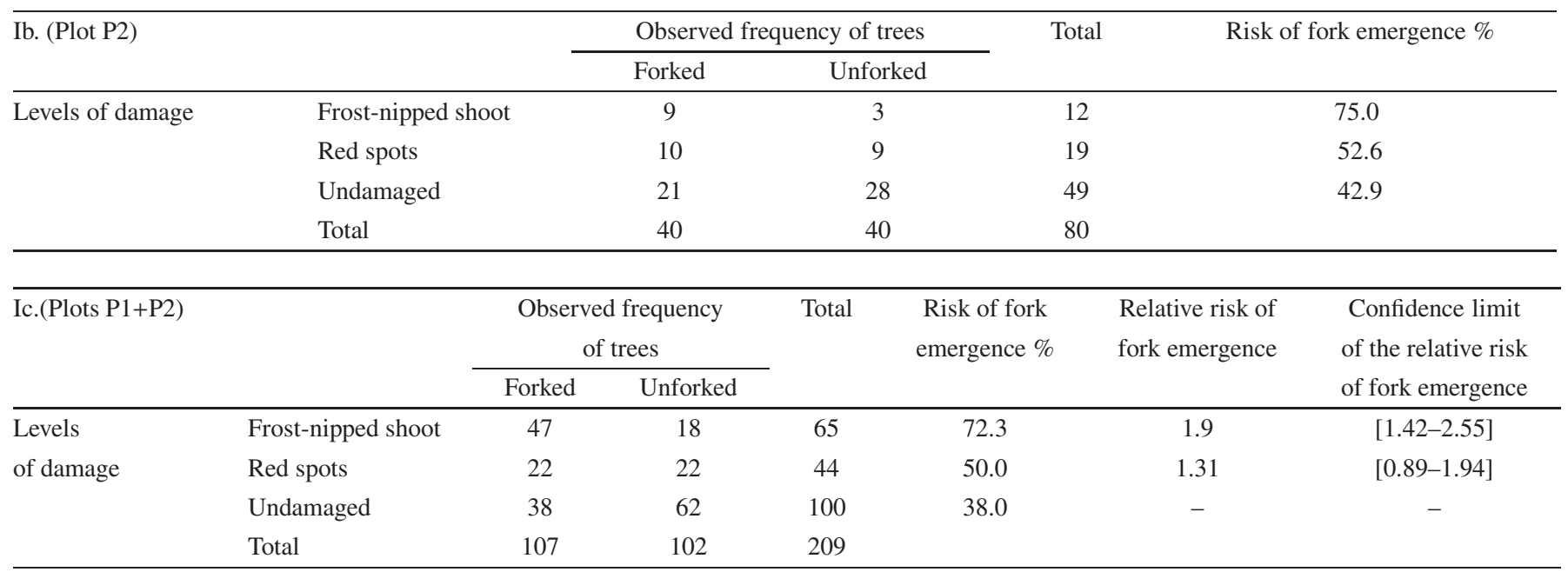

Table II. Main features of the logistic fit (Tab. IIa), parameters estimates (Tab. IIb), and comparison of the effect of damage (Tab. IIc). The fit was performed on the data collected in plots P1 and P2 (reference level: frost-nipped shoots). The comparisons (Tab. IIc) are based on the method of contrasts. Comparisons concerned P1 + P2 data and also P1 data once the logistic model adjusted on P1 data only.

\begin{tabular}{|c|c|c|c|}
\hline \multicolumn{4}{|c|}{ IIa. Main features of the model: logit ( proba[one fork or more] ) $=$ Intercept $+B_{\text {damage }}$} \\
\hline $\operatorname{Pr}>$ Chisq $<0.0001$ & RSQUARE $=0.09$ & $\begin{array}{l}\text { Max-rescaled } \\
\text { Rsquare }=0.12\end{array}$ & $C=0.66$ \\
\hline \multicolumn{4}{|c|}{ IIb. Parameters estimates } \\
\hline \multirow{4}{*}{ Levels of damage } & Intercept & 0.1567 & $\operatorname{Pr}>$ Chisq $=0.305$ \\
\hline & Frost-nipped shoot & 0 & \\
\hline & Red spots & -0.1567 & $\operatorname{Pr}>$ Chisq $=0.50$ \\
\hline & Undamaged & -0.6463 & $\operatorname{Pr}>$ Chisq $=0.0008$ \\
\hline \multicolumn{4}{|c|}{ IIc. Comparison of effects ( $P r>$ Chisq) with the contrast methodology } \\
\hline & Plots $\mathrm{P} 1+\mathrm{P} 2$ & Plot P1 \\
\hline \multicolumn{2}{|c|}{ Red spots compared to undamaged } & 0.18 & 0.22 \\
\hline \multicolumn{2}{|c|}{ Red spots compared to frost-nipped shoot } & 0.50 & 0.66 \\
\hline \multicolumn{2}{|c|}{ Frost-nipped shoot compared to undamaged } & 0.0008 & 0.004 \\
\hline
\end{tabular}




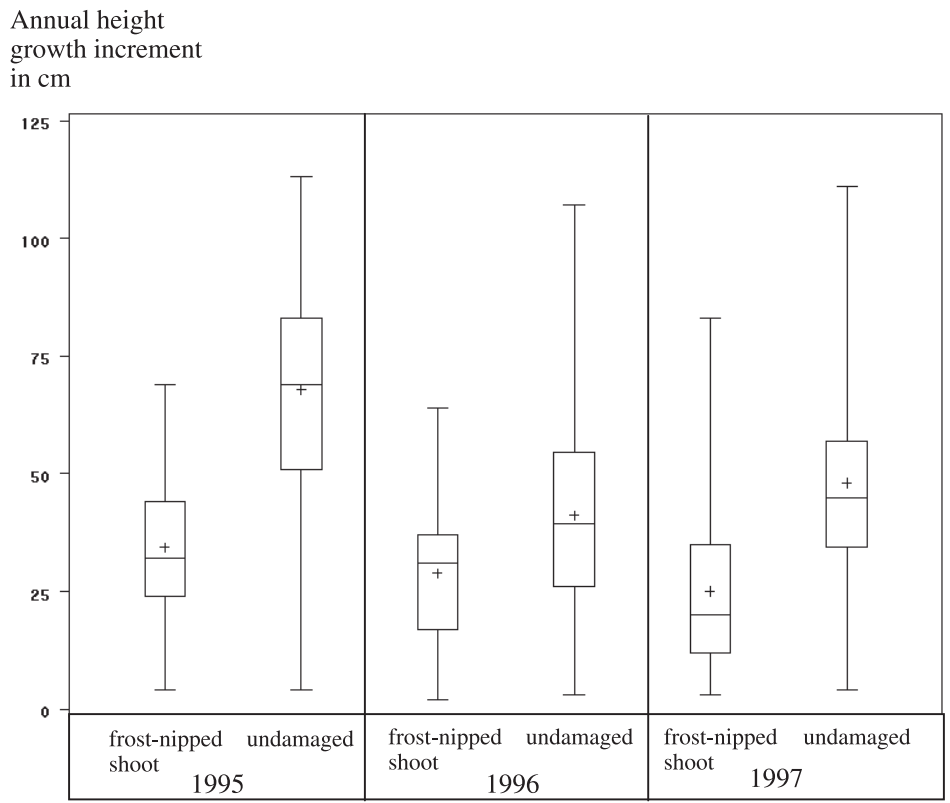

Figure 2. Box-plots of annual height growth increment in 1995, 1996 and 1997 for "frost-nipped shoot" and "undamaged" damage levels in plots $\mathrm{P} 1$ and $\mathrm{P} 2$ together (+ indicates the mean).

plant), as well as the air cooling dynamics, the height reached by the plant and its phenology [4], it would be especially necessary to acquire as much information as possible on the phenology which varied widely from one individual to another. In the lack of such a statistical model, the consequences of frost on the emergence of fork, even if the frost was well defined, could not be estimated accurately without knowing the immediate damage it had caused.

We identified 3 levels of immediate damage: trees whose shoots were totally frost-nipped, others where only the leaves were affected, and finally, others with undamaged shoots. The importance of this notation appeared progressively. Firstly, the identification of these 3 levels of damage demonstrated (1) that they were linked closely to tree height in different ways depending on the plot studied and (2) the presence of a spatial variation of the frost damage. Secondly, the intermediate damage level showed a risk of fork emergence which was intermediate too, and this reinforced the hypothesis that forking was a result of damage to the spring shoot. Thus according to general epidemiological laws, the causal nature of a relationship was particularly well demonstrated when the emergence of a phenomenon was increased by increasing the level of the risk factor [10]. Finally, the logistic model, applied to the probability of fork presence in plots P1 and P2 together, confirmed that "damage" was an explanatory factor which was much significant than the other variables and factors available.

Thus overall, the damage factor had both a statistical and a causal value, i.e. functional and more precisely morphogenetic. This confirmed the relevance of taking this factor into account before any other variable or factor.

Forking has been defined according to the criteria tested in our experimental sites for several years, for oak as well as beech [25]. It is an objective definition, based on the relative sizes of the branches making up the fork, with a minimum age of 3 years for each arm. This allows one to ignore the numerous temporary forks which have little effect in terms of tree morphology, wood technology and silviculture. This definition contributed to the conception of a survey strategy which could easily be applied to large long term surveys in forestry trials.

The decision to consider only the forks developed on the 1994 shoot of the main axis was in line with the aim of our study which was to determine and quantify the most direct effects of the frost. However this choice might have resulted in a slight under estimation of the effect of the late frost. So, it is also possible that in certain cases, the lateral shoots, little or unaffected by the frost, situated on the shoots prior to 1994, might have been favoured by the frost-nip of the terminal shoot. Several points should be emphasised. Firstly, under our experimental conditions, this situation seemed unlikely, as plants with frost-nipped terminal shoots, suffered frost-nip of shoots on the entire plant. Secondly, the risk of supplementary forks appearing would only slightly accentuate the negative consequences of the frost. Finally, to be tested, this risk required the individual additional examination of a large number of branches which would have considerably enlarged the survey.

The risk of fork emergence of $71.7 \%$ obtained in plot $\mathrm{P} 1$, in the case of complete damage of the terminal shoot is considerable especially as it concerns 3 -year-old forks. This high level suggests a certain persistence of forks caused by frosts, from their occurrence in 1995 until being surveyed in 1997. Based on general observations, Drenou [13] estimated that the presence of such accidental forks, as opposed to forks of different origins, could only be reduced by formative pruning. If it is true that forks due to frost damage are particularly persistent this would worsen the impact of frost damage. These 
differences in fork persistence depending on the cause of their emergence merits further tests.

Conversely, in $28.3 \%$ of the cases, a single axis rapidly relayed the main axis which had suffered frost-nip. A single new principal axis, within 3 years, in $28.3 \%$ of the cases, was a very interesting phenomenon which could only be quantified by the type of experimental approach that we used. The increase in the risk of fork emergence observed for less severe frost damage of leaves was not significant. This intermediate damage level may include variable intensities of changes in leaf, apical meristem and axillary bud viability, which were not taken into account in our observations. In any case, we cannot consider this damage to be unimportant, without more information.

Plants showing damage at the "frost-nipped shoot" level had a risk of fork emergence which was more than twice as high as those showing "no damage". The relative risk measured the relationship between the risk factor (which is damage in this case) and the frequency of the flaw (forking in this case) for one individual. Thus from the relative risk value of 2 , it could be deduced that an individual with a frost-nipped shoot was twice as likely to show a fork as an undamaged individual. This value which was already high, should be considered to be a minimum value because our control with no frost damage consisted of the most vigorous beech trees of the plot which also tended to be the most forked [14], demonstrated by the particularly high risk of fork emergence $(33.3 \%)$ calculated.

Relative risk of fork emergence and the attributive fraction of risk are two complementary concepts. Relative risk of fork emergence expresses the intensity of the individual reaction to potential damage and will contribute to the hierarchy of factors determining the emergence of forks. It is particularly important to transmit this information to forest managers engaged in a single-tree silviculture whose aim is to maximise the quality of a few individuals. The attributive fraction of risk takes the overall severity of the damage into account. Knowledge of the possible values of the attributive fraction of risk is useful for the forest manager to be able to justify forestry work to be carried out at the compartment scale.

In plot P1, these two concepts led us to conclude that the impact of frost was very unfavourable. In plots P1 and P2 together, although the relative risk in the presence of frostnipped shoots was equivalent (1.9 for P1 and P2 together versus 2.15 for P1) the attributive fraction of risk is lower, meaning that the "population" effect of the frost damage is slightly over-estimated in $\mathrm{P} 1$ compared to $\mathrm{P} 1+\mathrm{P} 2$, this likely due to the high proportion of short trees in $\mathrm{P} 1$ which were more severely damaged.

The forks which appeared on trees with frost-nipped shoots developed on plants for which growth was low in 1995 and also in the following years (with means of about $30 \mathrm{~cm}$ for each of the 3 years). After their retrospective study, Nicolini and Caraglio [24] assumed that the emergence of vertical lateral axes (of which some would contribute to more or less long lived forks) are largely influenced by annual height growth and would only become important in open plantations above a threshold annual elongation rate (AER) of $50 \mathrm{~cm}$. These results could not be confirmed by our work, and we have to con- clude that under the special circumstances of a late frost, AER was not determinant in the phenomenon of fork incidence. In addition, the partial or even lacking information which it was possible to collect in retrospective studies, about past exposure to risk factors, seriously restricted the pertinence of the conclusions that could be drawn. In addition the present study showed that the upper limit of stem length with frost damage in plains might be much higher than the $2 \mathrm{~m}$ usually evoked [12,31]. The forester should pay great attention during this critical phase of the formation of high quality butt-log wood, in areas where the forest stand is particularly sensitive to frost. In zones with high frost risk, it is recommended that silvicultural techniques to reduce this risk should be used preventatively, for instance, the maintenance of lateral forest shelter $[2,4]$ or curative measures to reduce its impact by rational fork pruning $[1,18,19]$.

\section{CONCLUSIONS AND PERSPECTIVES}

Our results showed that damage following a late frost may be an important risk factor regarding the incidence of forks which contribute to a degradation of the shape of beech trees.

The late frost, for which we have determined the consequences by analysing the causal relationship between damage and forking, presented special characteristics in terms of intensity, duration, or time of occurrence, which we do not know exactly. In the case of other late frosts, these characteristics may vary widely and so may lead to the same or other damage, which is even more severe.

As a result of this study, we only possess the forking probability for the damage levels observed. To complete our understanding of the effect of damage and consequently our understanding of the effect of late frosts we need to carry out the same kind of "cohort study", following frost causing the same levels of damage or even more severe damage and/or occurring on bigger, more vigorous plants.

It would also be possible to consider using artificial damage experimentally as has already been done for example on sessile oak [11] or on ash [26]. The number of plants receiving the different damage levels is thus controlled and it would be possible to eliminate the strong correlation between tree height and type of damage. This control was not possible in our experiment.

Forking, apart from its decisive impact on the development of the $\log$ and its quality, also plays a certain adaptive role [13] because it allows the plant to react to damage. Damage is a relatively common phenomenon, which cannot be separated from tree development. Until recently, reiterations, especially traumatic ones, were considered to be random and thus impossible to quantify [7], as opposed to architectural structures which accumulate sequentially, during the growth of the stem [6]. On the contrary, our study proved that quantification is possible and that the models inspired to a greater extent by epidemiological methods rather than architectural ones, were quite capable of identifying the causes and quantifying their effects. Four aspects should be considered, individually, and then in sequence: incidence, persistence, presence and shedding. 
The literature does not reveal any information on the persistence of forks or how it is determined. At our site this was not studied. It did not seem to be relevant as most of the damage was concentrated on the less vigorous trees which would disappear in the short or mid-term. However research on the determinism of fork persistence is important from two opposing points of view. Firstly, until a log has reached an acceptable commercial length it is important to find ways of accelerating the decline of one of the arms of the fork and consequently its disappearance. Conversely, it may be desirable to retain the lowest forks once a sufficiently long log has been obtained, so that they can contribute to a large crown system. Nevertheless, the mechanically weak zone where the arms of the fork are inserted should also be taken into account as this might be a disadvantage during occurrence of strong wind.

To consider all the relationships between frost and forking, one should also consider other types of frost, for example, early frost, which is less frequent than late frost [27], and winter frost. The consequences of early or winter frosts on forking are still speculative [22] and remain to be demonstrated formally. Consideration of the effects of other types of frost is very relevant, as in the future, the risk of early or winter frosts in France and on beech may increase due to the effect of climatic changes [5].

Acknowledgements: We warmly thank F. Bernier and G. Menoret for technical assistance, A. Nys for translation into English, and T. Nedeltcheva for translation from Bulgarian into French of the paper from Botev N. [9].

\section{REFERENCES}

[1] Armand G., Un itinéraire de taille et élagage du hêtre, Forêt Entreprise 132 (2000) 39-41.

[2] Armand G., Ningre F., Itinéraires sylvicoles en futaie régulière, in : Le Hêtre autrement, IDF, Paris, 2002, pp. 61-138.

[3] Aussenac G., Gelées tardives et jeunes peuplements forestiers, Rev. For. Fr. 22 (1970) 463-467.

[4] Aussenac G., Étude des gelées tardives en relation avec les problèmes de reboisement, Ann. Sci. For. 30 (1973) 141-144.

[5] Aussenac G., Guehl J.M., Impacts sur la forêt et la sylviculture, in : Impacts potentiels du changement climatique en France au $\mathrm{XXI}^{\mathrm{e}}$ siècle, Ministère de l'environnement, 1998, pp. 81-87.

[6] Barthelemy D., Caraglio Y., Costes E., Architecture, gradients morphogénétiques et âge physiologique chez les végétaux, in Modélisation de l'architecture des végétaux, INRA éditions, 1997, pp. $89-136$

[7] Bell A.D., Plant form. An illustrated guide to flowering plant morphology, Oxford University Press, 1991.

[8] Bernard P.M., Régression logistique, Cours EPM-64312, Département de Médecine Sociale et Préventive, Université de Laval Canada, 1999, http://w3.res.ulaval.ca/cours-epm-64312.

[9] Botev N., [The late spring frost as a factor for development of bifurcated shoots of the common beech (Fagus sylvatica L.)], Lesotekhnicheski Universitet Yubileen sbornik nauchni dokladi: 75 godini visshe lesotekhnichesko obrazovanie v Bulgariya Sektsiya Gorsko stopanstvo, 2000, pp. 373-376.
[10] Bouyer J., Hemon D., Cordier S., Derriennic F., Stucker I., Stengel B., Clavel J., Épidémiologie. Principes et méthodes quantitatives, Éditions INSERM, 1995.

[11] Chaar H., Colin F., Leborgne G., Artificial defoliation, decapitation of the terminal bud and removal of the apical tip of the shoot in sessile oak seedlings and consequences on subsequent growth, Can. J. For. Res. 27 (1997) 1614-1621.

[12] Cochet P., Étude et culture de la Forêt, Engref, 1977.

[13] Drenou C., Les fourches : un problème de taille, Forêt Entreprise 108 (1996) 43-47.

[14] Falcone P., Keller R., Le Tacon F., Oswald H., Facteurs influençant la forme des feuillus en plantation, Rev. For. Fr. 38 (1986) 315-323.

[15] Galoux A., La variabilité génécologique du hêtre commun (Fagus silvatica L.) en Belgique, Groenendaal-Hoeilaart, Station de recherches des eaux et Forêts, Travaux série A, $\mathrm{N}^{\circ} 11,1966$.

[16] Hauch L., Die Wirkung des Spätfrostes in jungen Buchenwaldungen, Forstwiss. Cent. bl. (1909) 307-322.

[17] Hubert M., Les dégâts du gel : attention aux cimes fourchues, Forêt de France 343 (1991) 26.

[18] Joyce P.M., Huss J., Mc Carthy R., Pfeifer A., Hendrick E., Growing Broadleaves. Silvicultural guidelines for Ash, Sycamore, Wild Cherry, Beech and Oak in Ireland, Coford, 1998.

[19] Kerr G., Boswell R.C., The influence of spring frosts, ash bud moth (Prays fraxinella) and site factors of forking young ash (Fraxinus excelsior) in southern Britain, Forestry 74 (2001) 29-40.

[20] Khristov K.H., Botev N.I., Effects of late spring damage on the increment of beech, Gorskostopanska-Nauka 18 (1981) 19-27.

[21] Kurth A., Untersuchungen über Aufbau und Qualität von Buchendickungen, Ann. Inst. Féd. suisse Rech. For. 24 (1946) 581-658.

[22] Le Tacon F., La plantation en plein découvert : une des causes de la mauvaise forme du hêtre dans le Nord-Est de la France, Rev. For. Fr. 35 (1983) 452-461.

[23] Mathieu D., Les conséquences des gels tardifs de mai 1995 sur les peuplements forestiers, Les cahiers du DSF 1 (1996) 22-23.

[24] Nicolini E., Caraglio Y., L'influence de divers caractères architecturaux sur l'apparition de la fourche chez le Fagus sylvatica, en fonction de l'absence ou de la présence d'un couvert, Can. J. Bot. 72 (1994) 1723-1734.

[25] Ningre F., Une définition raisonnée de la fourche du hêtre, Rev. For. Fr. 59 (1997) 32-40.

[26] Ningre F., Cluzeau C., Le Goff N., La fourchaison du frêne en plantation : causes, conséquences et contrôles, Rev. For. Fr. 44 (1992) 104-114.

[27] Ningre F., Menoret G., Bernier F., Le gel de mai 1995, une occasion pour en savoir plus sur le comportement du hêtre en plantation, Forêt Entreprise 117 (1997) 57-63.

[28] Peik K., Auswirkungen von Spätfrostschäden auf das Höhenwachstum junger Buchen verschiedener Herkunft, Allg. Forst. Jagdztg. 147 (1976) 142-146.

[29] Rast E.D., Brisbin R.L., Six year effects of two late spring frosts on Appalachian hardwoods, North. J. Appl. For. 4 (1987) 26-28.

[30] Vernier M., Teissier du Cros E., Variabilité génétique du hêtre. Importance pour le reboisement en Picardie et en Normandie, Rev For. Fr. 68 (1996) 7-20.

[31] Teissier du Cros E., Le Tacon F., Nepveu G., Parde J., Perrin R., Timbal J., Le Hêtre, INRA éditions, 1981. 